\title{
Possible deferral of diagnostic and therapeutic procedures for patients with abnormal screening tests results in cervical cancer secondary prevention in current SARS-CoV-2 pandemic Interim guidelines of the Polish Society of Gynecologists and Obstetricians and the Polish Society of Colposcopy and Cervical Pathophysiology
}

\author{
Robert Jach ${ }^{1 *}\left(\mathbb{D}\right.$, Maciej Mazurec ${ }^{2 *}\left(\mathbb{D}\right.$, Martyna Trzeszcz ${ }^{2,3 *}$, Mariusz Zimmer ${ }^{4 *}(\mathbb{C})$ \\ ${ }^{1}$ Division of Gynecologic Endocrinology, Jagiellonian University Medical College, Cracow, Poland \\ ${ }^{2}$ Corfamed Woman's Health Center, Wroclaw, Poland \\ ${ }^{3}$ Division of Pathology and Clinical Cytology, University Hospital in Wroclaw, Poland \\ ${ }^{4} 2^{\text {nd }}$ Department of Gynecology and Obstetrics, Wroclaw Medical University, Wroclaw, Poland \\ *Authors should be deemed the first authors due to the equal contribution to this article
}

\begin{abstract}
The Polish Society of Gynecologists and Obstetricians and Polish Society of Colposcopy and Cervical Pathophysiology Interim Guidelines goal at aiding gynecologists in providing a cervical cancer prevention care during the evolving SARS-CoV- 2 pandemic. Presented guidelines were developed on a review of limited data and updated when new relevant publications were revealed. Timing for deferrals of diagnostic-therapeutic procedures were mostly covered in the guidelines. Also, a support for the existing Polish recommendations on abnormal screening results in a subject of minor and major screening abnormalities terminology were given. The guidelines are obligatory for the specified COVID-19 pandemic period only and they might be changed depending on the new available evidence.

Key words: cervical cancer prevention; abnormal screening results; HPV testing; cervical cytology; selfsampling; SARS-CoV-2 pandemic; guidelines
\end{abstract}

Ginekologia Polska 2020; 91, 7: 428-431

Update: 2. May 2020

The recommendations present current management that can be modified and changed in justified cases, after careful analysis of a given clinical situation, which in the future may constitute grounds for their modification and updating. Interim guidelines are obligatory for specified period only.

\section{INTRODUCTION}

The current national epidemiological situation rapidly changed due to the SARS-CoV-2 pandemic and a public health threat has arisen [1,2]. The clinical management and diagnostic-therapeutic procedures performed so far in the secondary cervical cancer prevention in Poland need to be revisited to avoid the unnecessary virus spreading. The temporary guidelines for the pandemics time have been already introduced by some countries [3] for the patients' management with abnormal screening tests results. Understanding the pandemic period restrictions, Polish interim guidelines for deferral of all non-essential medical office 
Table. 1. Recommended management during the SARS-CoV-2 pandemic in women with the minor cervical cancer screening abnormalities. The different screening models were given

\begin{tabular}{|c|c|}
\hline Model of screening and detected minor screening abnormalities & Recommended management* \\
\hline Primary cytology & \multirow{8}{*}{$\begin{array}{l}\text { 1. Deferral of diagnostic tests up to } 6-12 \text { months } \\
\text { or } \\
\text { 2. Continuation of screening that do not require leaving the } \\
\text { place of residence with the use of previously sampled } \\
\text { liquid-based cytologic material (if applicable) }\end{array}$} \\
\hline ASC-US or LSIL & \\
\hline ASC-US or LSIL followed by negative HRHPV testing & \\
\hline ASC-US or LSIL followed by negative $\mathrm{p} 16 / \mathrm{Ki} 67$ test & \\
\hline ASC-US or LSIL followed by positive HRHPV N16/N18 and negative $\mathrm{p} 16 / \mathrm{Ki} 67$ testing & \\
\hline Primary co-testing & \\
\hline ASC-US or LSIL HRHPV-negative & \\
\hline ASC-US or LSIL HRHPV N16/N18-positive & \\
\hline
\end{tabular}

appointments and elective procedures in the secondary cervical cancer screening have been developed, pursuant to the President of the Polish Society of Gynecologists and Obstetricians (PTGiP) statement of the $20^{\text {th }}$ of March 2020, and the joint recommendations of the Polish national consultants in obstetrics and gynecology together with the national consultants in perinatology of the $19^{\text {th }}$ of March $2020[4,5]$. Guidelines for possible deferral of diagnostic and therapeutic procedures in cervical cancer prophylaxis are obligatory for the specified COVID-19 pandemic period only.

\section{RECOMMENDATIONS}

The Interim guidelines are supplementary to the existing Polish recommendations [6-8] for the secondary cervical cancer prevention in the subject of a terminology for minor and major screening abnormalities.

\section{Minor screening abnormalities - a definition and the recommended management}

Minor screening abnormalities in the pre-colposcopic stage encompass the following screening test results:

- in the primary cytology-based model the following results:

- ASC-US,

- LSIL,

- ASC-US or LSIL followed by negative HRHPV test,

- ASC-US or LSIL followed by negative p16/Ki67 test,

- ASC-US or LSIL followed by positive HRHPV type non-16/non-18 and negative $\mathrm{p} 16 /$ Ki67 test;

- in the primary cotesting-based model the following results:

- ASC-US or LSIL HRHPV-negative,

- ASC-US or LSIL HRHPV types non-16/non-18-positive.

Patients with minor cervical cancer screening abnormalities may have deferred of diagnostic tests up to 6-12 months [3].

The following management in the secondary cervical cancer prevention in women with abnormal minor screen- ing tests results during the SARS-CoV-2 pandemic period is recommended (Tab. 1).

Continuation of previously started screening that do not require leaving the place of residence is recommended, especially with the use of the liquid-based preparation systems. This concerns molecular testing for the high-risk HPV (HRHPV) and immunocytochemical p16/Ki67 testing in a case of ASC-US or LSIL cytology result [6-8].

HRHPV selfsampling at home is recommended if a primary molecular testing is required, or if a reflex testing is required in case of an ASC-US or LSIL abnormal cytology result [9].

\section{Major Screening Abnormalities - a definition and the recommended management}

Major screening abnormalities in the pre-colposcopic stage encompass the following screening test results:

- in the primary cytology-based model the following results:

- ASC-H,

- $\mathrm{HSIL}$

- ASC-US or LSIL followed by positive HRHPV type 16 and/or 18 ,

- ASC-US or LSIL followed by positive p16/Ki67 test;

- in the primary cotesting-based model the following results:

- HRHPV type 16 and/or 18 positive,

- $\quad$ ASC-H, HSIL and AGC cytology results, regardless the HPV status;

- in the primary HRHPV-based selfsampling model HRHPV type 16 and/or 18 positive. For HRHPV types non-16/non-18 positive results obtained in selfsampling a management algorithm depends on clinical situation and screening history.

Patients with major cervical cancer screening abnormalities may have deferred of diagnostic tests and treatment maximum up to 3 months [3]. 
Table. 2. Recommended management during the SARS-CoV-2 pandemic in women with the major cervical cancer screening abnormalities. The different screening models were given

\begin{tabular}{|l|l|}
\hline Model of screening and detected major screening abnormalities & Recommended management* \\
\hline Primary cytology & \\
\hline ASC-H or HSIL & $\begin{array}{l}\text { Deferral of diagnostic tests or treatment maximum up to } \\
3 \text { months }\end{array}$ \\
\hline ASC-US or LSIL followed by positive HRHPV 16 and/or 18 & \\
\hline ASC-US or LSIL followed by positive p16/Ki67 & \\
\hline Primary co-testing & \\
\hline Positive HRHPV 16 and/or 18 & \\
\hline ASC-H, HSIL, AGC regardless HRHPV status &
\end{tabular}

ASC-US - atypical squamous cells of undetermined significance; LSIL — low-grade squamous intraepithelial lesion; ASC-H — atypical squamous cells cannot exclude HSIL; HSIL — high-grade squamous intraepithelial lesion; AGC — atypical glandular cells; HRHPV — high-risk human papillomavirus type

*In individual cases the management might be modified depending on a clinical- and a patient-related status and/or depending on changes in a present healthcare environment

The following management in the secondary cervical cancer prevention in women with abnormal major screening tests results during the SARS-CoV-2 pandemic period is recommended (Tab. 2).

\section{Histologic HSIL treatment}

Specific guidelines of the gynecological societies adapted for the COVID-19 pandemic vary worldwide in the framework of histologic HSIL priority treatment $[10,11]$ and available data and evidence are limited. The conization due to histologic HSIL is considered by the European Society of Medical Oncology as a low-priority medical procedure while including an oncologic cervical cancer treatment of all clinical stages [10]. At the end of April, the joint American statement (of the eight gynecological and non-gynecological societies) was revealed in which authors took into account an epidemiological situation in a post-peak infectious curve when the risk of SARS-CoV-2 infection will be diminished and 'a normal new' will appear. In that document for benign gynecological indications on re-introduction of hospital and office-based procedures for the practicing gynecologists the CIN2 or CIN3 (HSIL) treatment was incorporated as an elective surgery of high acuity $[12,13]$. Therefore, Polish interim guidelines suggest in the decision-making that a prioritization of patients should be established after a careful analysis of a clinical status and a patient-related situation, and also should be modified according with the dynamically changing national healthcare environment related to COVID-19.

\section{Invasive cervical disease}

In patients with suspected invasive cervical disease the recommendations for a clinical management remain unchanged.

\section{SUMMARY}

The above Polish interim guidelines for a possible deferral of diagnostic and therapeutic procedures for patients with abnormal screening tests results in cervical cancer secondary prevention in current SARS-CoV-2 pandemic present not the final management to proceed the patients with abnormal screening test results in the secondary cervical cancer prevention. They do not replace a full clinical assessment of each individual case. The guidelines should always be considered in the context of the patient's health interest. They may change depending on new available data.

\section{REFERENCES}

1. The World Health Organization. WHO Director-General's opening remarks on COVID-19. https://www.who.int/dg/speeches/detail/who-director-general-s-opening-remarks-at-the-media-briefing-on-covid-19---11-march-2020 (11 March 2020).

2. Rozporządzenie Rady Ministrów z dnia 26 kwietnia 2020 r. zmieniające rozporządzenie $w$ sprawie ustanowienia określonych ograniczeń, nakazów i zakazów w związku z wystąpieniem stanu epidemii. http:// dziennikustaw gov pl/DU/2020/697 (Accessed 27 March 2020).

3. The American Society for Colposcopy and Cervical Pathology. ASCCP Interim Guideline for Timing and Treatment Procedures for Patients with Abnormal Cervical Screening Tests. https://www.asccp.org// covid-19-resources (20 March 2020).

4. Zalecenia dla kobiet $w$ okresie okołoporodowym w związku z ogłoszonym na obszarze Rzeczypospolitej Polskiej stanem epidemii w związku z zakażeniami wirusem SARS-CoV-2. .https://www.gov. $\mathrm{pl} /$ web/zdrowie/zalecenia-dla-kobiet-w-okresie-okoloporodowym-w-zwiazku-z-zakazeniami-sars-cov-2 (20 March 2020).

5. Rekomendowana ścieżka postępowania dla kobiet w ciąży COVID-19. https://www.ptgin.pl/rekomendowana-sciezka-postepowania-dla-kobiet-w-ciazy-covid-19 (21 March 2020).

6. Józefiak A, Kędzia W, Kotarski J, et al. Guidelines for application of molecular tests identyfying HR HPV DNA in the prevention of cervical cancer. Statement of experts from PGS (PTG) and NCLD (KIDL). Ginekol Pol. 2013; 84: 395-399.

7. National Cervical Cancer Screening Programme in Poland Coordinating Centre; Polish Gynaecological Society; Polish Society of Pathologists; Polish Society of Colposcopy and Uterine Cervix Pathology. Management of abnormal pap smear--consensus guidelines of the National Cervical Cancer Screening Programme in Poland Coordinating Centre, the Polish Gynaecological Society, the Polish Society of Pathologists, and Polish Society of Colposcopy and Uterine Cervix Pathology. Ginekol Pol. 2009 Feb. ; 80(2): 129-38.

8. Nasierowska-Guttmejer A, Kędzia W, Wojtylak S, et al. Polish recommendations regarding diagnostics and treatment of cervical squamous intraepithelial lesions according to the CAP/ASCCP guidelines. Ginekol Pol. 2016; 87(9): 670-676, doi: 10.5603/GP.2016.0066, indexed in Pubmed: 27723078.

9. Winer R, Lin J, Tiro J, et al. Effect of Mailed Human Papillomavirus Test Kits vs Usual Care Reminders on Cervical Cancer Screening Uptake, Precancer 
Detection, and Treatment. JAMA Network Open. 2019; 2(11):e1914729, doi: 10.1001/jamanetworkopen.2019.14729.

10. European Society for Medical Oncology. Management and Treatment Adapted Recommendations in the COVID-19 Era: Cervical Cancer. https://www.esmo.org/guidelines/cancer-patient-management-during-the-covid-19-pandemic/gynaecological-malignancies-cervical-cancer-in-the-covid-19-era (10 April 2020).

11. Ramirez PT, Chiva L, Eriksson AG, et al. COVID-19 Global Pandemic: Options for Management of Gynecologic Cancers. Int J Gynecol Cancer. 2020; 30(5): 561-563, doi: 10.1136/ijgc-2020-001419, indexed in Pubmed: 32221023.
12. SGS, SGO, ASRM, AAGL AUGS, IGCS, SFP, SRS. Joint Statement on Re-introduction of Hospital and Office-based Procedures in the COVID-19 Climate for the Practicing Urogynecologist and Gynecologist. https://www.sgo.org/wp-content/uploads/2020/04/Reintroduction-of-Hospital-and-Office-Procedures-in-the-COVID-19-Climate.pdf (April 2020).

13. LeBrun EW, Moawad N, Rosenberg E, et al. Coronavirus disease 2019 pandemic: staged management of surgical services for gynecology and obstetrics. American Journal of Obstetrics and Gynecology. 2020; 223(1): 85.e1-85.e19, doi: 10.1016/j.ajog.2020.03.038. 